\title{
LA METÁFORA DE LA TRADUCCIÓN COMO HERRAMIENTA PEDAGÓGICA INTERCULTURAL
}

\author{
A METÁFORA DA TRADUÇÃO COMO FERRAMENTA PEDAGÓGICA \\ INTERCULTURAL
}

\author{
THE METAPHOR OF TRANSLATION AS AN INTERCULTURAL PEDAGOGICAL \\ METHOD
}

\section{Daniel Berisso ${ }^{1}$}

\begin{abstract}
RESUMO
Neste artigo, considera-se a abordagem da pedagogia intercultural de uma perspectiva ético-política. Para tanto, postula-se que o fenômeno da transposição didática, em contextos interculturais, deve ser entendido a partir da metáfora da tradução. Desta forma, a tradução não é entendida em seu sentido técnico, mas tratada em sua precisão impossível; e dessa impossibilidade é considerado o ganho epistemológico que ocorre nas áreas de contato dialógico entre culturas.
\end{abstract}

PALAVRAS-CHAVE: Intercultural. Etica. Transposição. Tradução. Pedagogia.

\begin{abstract}
In this article, the approach of intercultural pedagogy from an ethical-political perspective is considered. To this end, it is postulated that the phenomenon of didactic transposition, in intercultural contexts, must be understood on the basis of the metaphor of translation. In this way, translation is not understood in its technical sense, but addressed in its impossible accuracy; and from this impossibility is considered the epistemological gain that occurs in the areas of dialogical contact between cultures.
\end{abstract}

KEYWORDS: Intercultural. Ethics. Transposition. Translation. Pedagogy

\section{RESUMEN}

En este artículo se plantea el abordaje de la pedagogía intercultural desde una perspectiva ético-política. Para ello se postula que el fenómeno de la trasposición didáctica, en contextos interculturales, debe ser entendido sobre la base de la metáfora de la traducción. De este modo, la traducción no es comprendida en su sentido técnico, sino abordada en su imposible exactitud; y a partir de esa imposibilidad se considera la ganancia epistemológica que se produce en las zonas de contacto dialógico entre culturas.

PALABRAS CLAVE: Intercultural. Ética. Trasposición. Traducción. Pedagogía.

\section{CONSIDERACIONES INICIALES}

Este texto guarda continuidad con estudios emprendidos con anterioridad, sobre todo en ¿Qué clase de dar es el dar clase? (2015), acerca de la importancia de la traducción como

\begin{tabular}{|c|c|c|c|}
\hline Rev. Ciências Humanas & Frederico Westphalen, RS & Pg. 63-83 & Maio/Agosto 2019 \\
\hline \multicolumn{2}{|c|}{ Recebido em: 26/05/2019 } & \multicolumn{2}{|c|}{ Aceito em: 16/09/2019 } \\
\hline
\end{tabular}




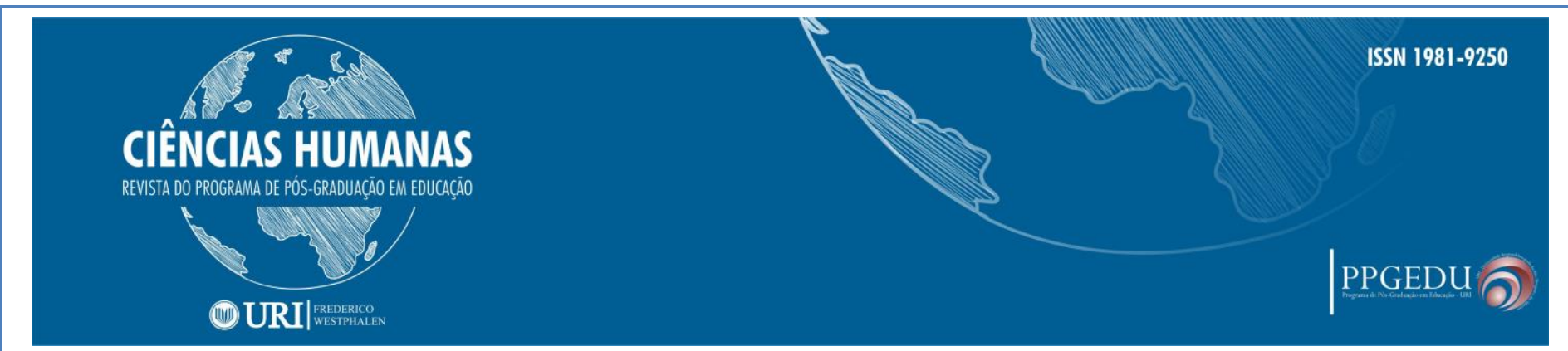

práctica ligada a la trasposición didáctica en contextos interculturales. En esta ocasión tomo como punto de partida de mi argumentación a un filósofo argentino de gran trayectoria académica aunque, lamentablemente, muy poco citado en las producciones filosóficas actuales: Rodolfo Agoglia (1920-1985). En su ensayo "la cultura como facticidad y reclamo" Agoglia (1982), ya desde el título de la obra, desarrolla dos aspectos del concepto "cultura", que pueden adaptarse perfectamente al campo de la "interculturalidad" y que revisten gran relevancia en el desarrollo de una actividad pedagógica intercultural. Me refiero a una propuesta educativa que, aparte de ser intercultural, exhiba una pretensión ético-política. Se trata de evitar el posible espejismo de que el mero pasaje de lo uno a lo múltiple es algo de por sí ético o político, sin que medie la interrogación acerca del "cómo" del pasaje. Es decir, se procura atender al modo específico de relación que se da entre los elementos que entran en contacto, más que de focalizar la mera facticidad de la relación.

Los conceptos de "facticidad" y de "reclamo" son elementos de primer orden, tanto en el nivel de una Filosofía de la cultura como en el de una Filosofía de la educación. La facticidad es lo que de facto, de hecho, una cultura es. Y la educación de la facticidad comprende la transmisión de contenidos culturales sin tener en cuenta la dialógica docentealumno (FREIRE, 2010; SANTOS, 2014), ni atender a los elementos que pueden ser dominantes, es decir, sin atender a la colonialidad cultural y pedagógica.

En los tiempos del populismo de mediados del siglo XX, el concepto de "sustitución de importaciones", llevado al plano de la producción intelectual, condujo a teóricos latinoamericanos, como el citado Agoglia (1982), a postular el deber ético-político de reclamar por una cultura nacional y popular. Es decir, para Agoglia, como para Paulo Freire, entre otros, no toda forma cultural debería dar lo mismo al filósofo o al alfabetizador crítico. Hay un trasfondo ético-político que sirve a la distinción entre lo auténtico y lo impostado. El populismo de esos años trató de rescatar las producciones y símbolos del campo nacional y popular, por fuera de los contenidos impuestos por la colonialidad pedagógica y la industria cultural. Se criticó la influencia de éstos últimos, su objetivo de alienar, esto es: de sacarnos del rol de productores culturales y fijarnos en una identidad consumista de valores y paradigmas acríticamente adoptados. 


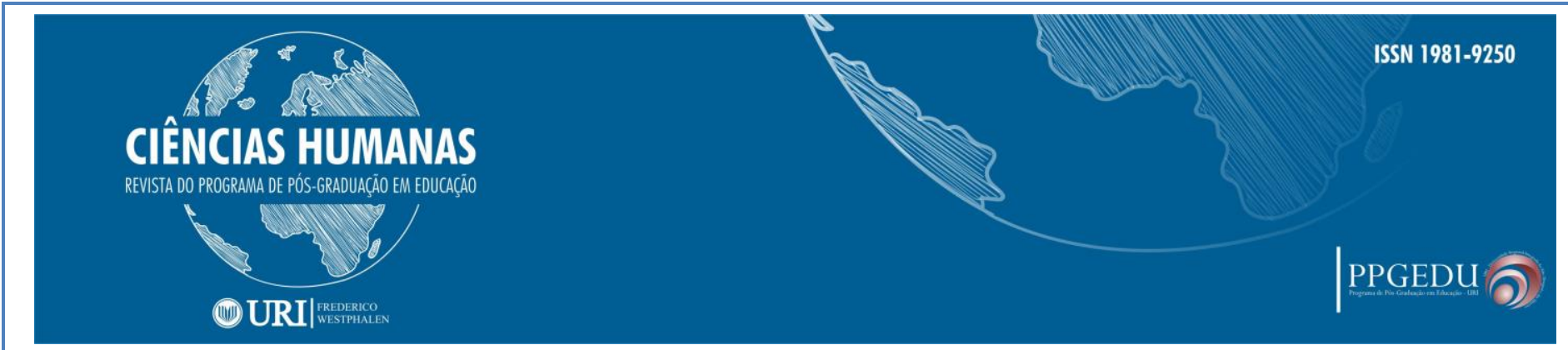

La experiencia filosófica y pedagógica en este terreno muestra hoy un escenario donde la crisis de fundamentos ontológicos, la intensificación del fenómeno migratorio, y la consecuente deconstrucción de las imágenes nacionales puras, otorgan especial importancia a los fenómenos de hibridez y de contacto intercultural. Entonces, las pautas de "facticidad" y "reclamo" cobran renovada elocuencia. Es decir, existe una interculturalidad fáctica o "de hecho" que es analizada científicamente por los antropólogos, pero también hay una interculturalidad como "reclamo" ético-político. Se trata de un deber ser intercultural, que implica nociones de hospitalidad y dialógica co-productiva. Y ante esto: ¿quién podrá erigirse en maestro o maestra de educación intercultural en valores, cuando los valores parecen ser pautas absolutamente relativas a cada cultura?

Pues bien, considero que la metáfora de la traducción, según se la entienda, puede ser un camino indicado para referirse a un método intercultural, mediador en la transmisión de saber entre culturas, según el cual una cultura no domina ni reduce a la otra y ambas conviven bajo el desideratum ético-político de la potenciación mutua. En otra parte ya he afirmado que la constatación científica de interculturalides de facto, que da cuenta de las variadas relaciones simbólicas y sociales que pueden entablarse entre culturas, se muestra insuficiente a la hora de denunciar el monoculturalismo, como variable asociada a la dominación. Se trata, entonces, de reivindicar -ética y políticamente- la interculturalidad como horizonte correctivo y utópico de aquellas facticidades que empobrecen y reducen la multiplicidad que caracteriza el devenir histórico de la especie humana.

\section{EL MÉTODO DE LA TRADUCCIÓN}

Lo dicho acerca de la interculturalidad se traslada, pues, a esa práctica que le es connatural: la traducción, estableciéndose distinciones. Por un lado, puede hablarse de "traducción" distinguiendo una serie de prácticas históricamente determinables que van desde la resistencia a la opresión. Por otro lado, puede pensarse en una ética de la traducción, pensamiento que pone en cuestión la modalidad donde la lengua extranjera es reducida a la propia. Se percibe un posible uso contrafáctico del concepto, según el cual este pueda ser 


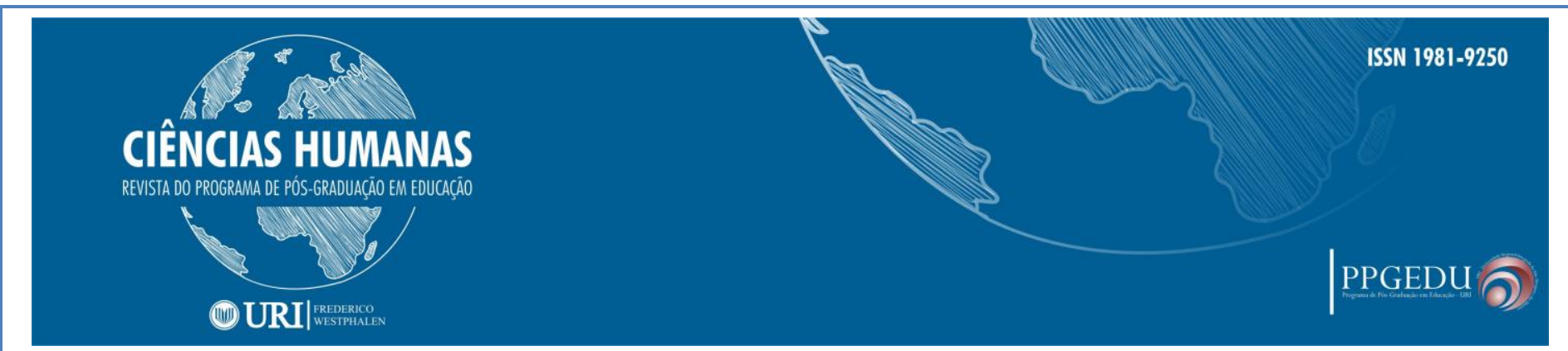

comprendido como praxis liberadora y, por lo tanto, signo inequívoco de apertura a la alteridad.

Traducir, como señala Eco, consiste un "decir casi lo mismo". Nuestra propuesta estriba en descubrir el sentido ético de dicho "casi lo mismo" (ECO, 2008, p.115); en comprender el "casi" no como indicativo de pobreza o falta de plenitud, sino como distintivo de ganancia ético-epistemológica que, justamente, delata y destruye la prepotencia encerrada en el afán de mismidad característico de la "colonialidad del saber" (CASTRO-GÓMEZ, 1993; 2007). La traducción, como también señalan Eco y Larrosa (2003) contiene un vínculo etimológico con la idea de "traición”. Debería, entonces, despojarse al término "traición" de la carga moralmente negativa que lo descubre como deserción ante un mandato de fidelidad. Hasta podría hablarse de una "ética de la infidelidad" conjugada a una "ganancia epistemológica" de la distorsión. En efecto, cuando quien traduce "altera" desde su mundo un texto dado, y quien lee es receptivo a dicha "alteración", el primero ejercita una ética de la toma de la palabra y, correlativamente, el segundo practica una "ética de la alteridad". Puede decirse, entonces, que el "casi lo mismo" o la "traición" brindan el espacio fronterizo que posibilita la articulación de la hospitalidad del yo y la palabra del otro (BERISSO, 2015).

La "metáfora" de la traducción está al servicio de lo que Fornet-Betancourt denomina “antropología contextual de la dignidad humana" (FORNET-BETANCOURT, 2009, p. 77). En tanto promotora de "dignidad", rompe con la interculturalidad fáctica para asumir una función utópica. El criterio en cuestión puede sostenerse solo si se trasciende el concepto técnico de "traducción" que conduce siempre al esquema vincular del mundo editorial.

Los teóricos de la traducción -como el mencionado Umberto Eco- circunscriben el campo analítico del término a la clásica tríada: autor, traductor, lector. De este modo la problemática de la traducción pasa a ser entendida como arte específico, de incumbencia profesional. Las tramas interculturales, en cambio, carecen de autor y no siempre cuentan con un mediador profesionalizado que oficie de medio entre una lengua y otra. Esta situación vivencial resalta el valor (ético) del "esfuerzo" en abrirse a un horizonte cultural ajeno.

Según Fornet-Betancourt, en línea con lo que aquí se viene sosteniendo, el pensamiento intercultural representa en bloque: "una propuesta programática para una nueva transformación de la filosofía” (FORNET-BETANCOURT, 2003, p. 9). A tono con el giro 


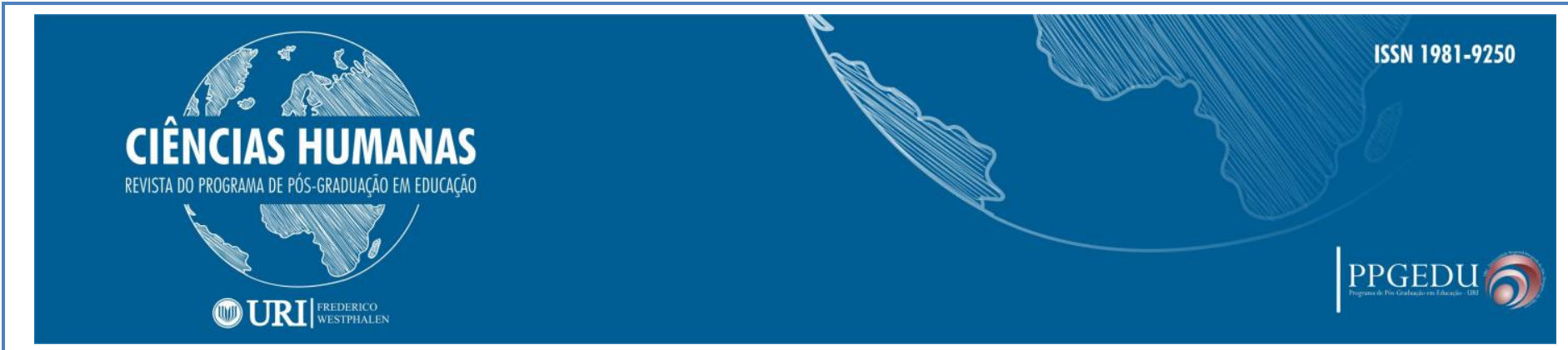

ético que privilegia la dignidad y la responsabilidad frente al primado de la ontología, la perspectiva intercultural de referencia representa el desafío -y el reclamo- de la convivencia solidaria entre seres de distintas culturas que como tales -y contra el reduccionismo que alienta la globalización capitalista- "se hacen prójimo” (BERISSO, 2015).

Ahora bien teniendo en cuenta la incidencia de toda transformación filosófica en las prácticas educativas, aquí se trata de medir este impacto en las estrategias de trasposición. Es preciso partir del carácter problemático de expresiones, tales como "saber sabio", "saber académico" o "sistema de expertos". Hay que decir, siguiendo a autores como FornetBetancourt o Mignolo (2001, 2009), que lo "sabio" o lo "experto" suele estar ligado a una matriz colonial y que, por lo tanto, se debería desactivar la idea de que occidente es el “escenario único" de toda producción filosófica o epistémica elevada.

Bajo la farsa ideológica de la superioridad de occidente se aísla al pensamiento de sus vínculos contextuales. Una de las fórmulas de combate a esta violencia epistémica consiste en "regionalizar la validez de las formas filosóficas sancionadas por la tradición occidental dominante" (FORNET-BETANCOURT, 2003, p. 13). Desplazar la filosofía de una exclusiva referencia al canon occidental, significa también expropiarla del discurso curricularprofesionalista de la "normalidad filosófica". Esta naturalización ha sido el estandarte de autores como Francisco Romero (FORNET-BETANCOURT, 2003, p. 104), partiendo de antecedentes claramente eurocéntricos en la región, como el positivismo de la Generación del '80 en la Argentina, o la llamada "iglesia positivista" del Brasil.

Como puede apreciarse, ese supuesto "saber sabio", del que habla Chevallard ${ }^{2}$ en su teoría de la transposición didáctica, se torna sensiblemente complejo. Por un lado se muestra múltiple en lo que hace a sus variables contextuales, por el otro, admite una pluralidad de prácticas y desarrollos en el interior mismo de un determinado universo cultural. No obstante, no cualquier manifestación puesta a competir con las fórmulas académicas es digna de reputación filosófica. Habría que aprender a estimar las mediaciones que elevan un saber, inédito en el marco del pensamiento enseñado, a la condición meritoria de lo enseñable. Por ahora quedémonos con esta observación metodológica del texto de Fornet-Betancourt: “Abrir

\footnotetext{
${ }^{2}$ Prestigioso matemático y didacta francés, que en las notas preparatorias a su curso, a propósito de la didáctica de las matemáticas, ofrece la versión, ya clásica, de la transposición didáctica, bajo el sugerente subtítulo: "Del saber sabio al saber enseñado".
}

\begin{tabular}{c|c|c|c}
\hline Rev. Ciências Humanas & Frederico Westphalen, RS & Pg. 63-83 & Maio/Agosto 2019 \\
\hline \multicolumn{2}{c}{ Recebido em: 26/05/2019 } & Aceito em: 16/09/2019 \\
\hline
\end{tabular}




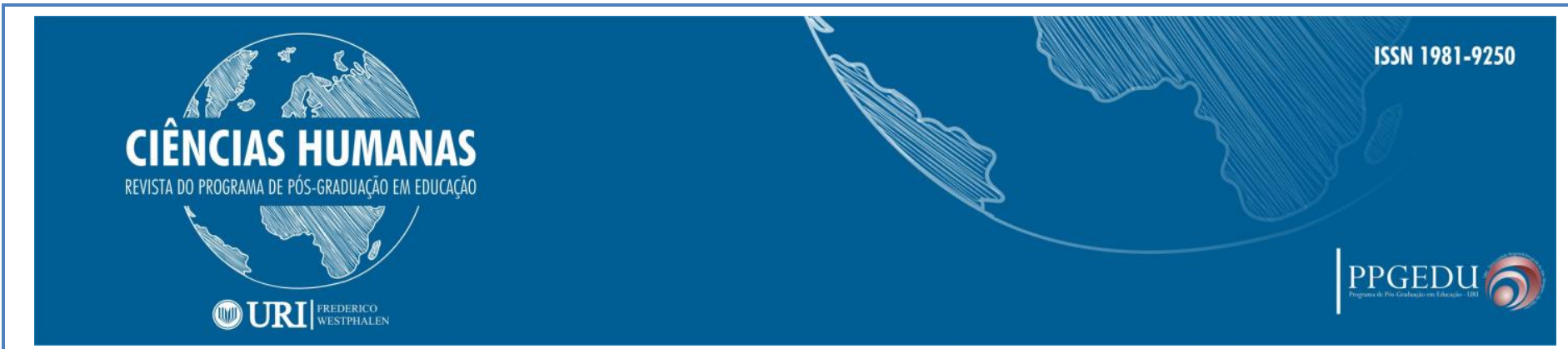

el horizonte del quehacer filosófico a otras formas de ejercicio y reconocimiento, como podrían ser, por ejemplo, el discurso oral o la articulación contextual de la vida cotidiana" (FORNET-BETANCOURT, 2003, p. 13). Para decirlo al modo de Kusch: deberíamos comprometernos con la "gravidez" de la cultura (KUSCH, 1987, p. 13) ${ }^{3}$. Sin embargo, la fidelidad a mundos o regiones y, con ello, la verificación de múltiples filosofías, y por lo tanto de múltiples éticas, sitúa al observador ante un problema clave para la transposición didáctica de sus expresiones teóricas y prácticas: el del universalismo frente al particularismo. La objeción que sale al cruce es obvia en el caso de la ética: o existe una ética universal, es decir, un patrón de medida general y a priori, lo cual derribaría cualquier intento de regionalización; o bien cada cultura tiene su ética, lo cual volvería imposible todo intento de enseñanza de valores en un contexto intercultural.

Según Fornet-Betancourt, la disputa entre los abanderados del patrón unitario y aquellos que defienden la inconmensurabilidad de mundos culturales está basada en un malentendido acerca de la universalidad. Entre los logros que el autor reconoce al pensamiento intercultural se destaca: "la corrección de la fragmentación posmoderna de la razón", es decir la asunción de una contextualidad que no produce "islas de razón" sino “zonas de traducción” (FORNET-BETANCOURT, 2003, p. 19). De ahí que se contribuya a la “superación del relativismo cultural (...) al leer la pluralidad desde la clave de la relación”, es decir, desde la sanción de una universalidad basada en "la relación" y no en el englobamiento o la reducción de partes a un Todo. Esta forma de universalidad conjura a un tiempo el esencialismo de la mismidad que pretende absorber en sí toda diferencia y las fijaciones etnocéntricas de aquellas culturas que pretenden revestir sus diferencias de un carácter sustancial y ahistórico. En filosofía es frecuente que los múltiples vanguardismos y escepticismos crean demasiado en las formulaciones oficiales de los ideales que niegan. De este modo, los ataques relativistas o particularistas a la noción de "universalidad" a menudo se

\footnotetext{
${ }^{3}$ El concepto de "gravidez" es central en la obra de Rodolfo Kusch. De los múltiples textos que pueden ilustrar el uso de esta noción, elegí el capítulo "Geocultura del pensamiento" en Esbozo de una antropología filosófica americana. Allí expresa: “[...] Quizá lo propio de la filosofía entre nosotros ha de ser, ya no su enseñanza misma, sino advertir en qué medida se deforma a causa de la gravidez local". Esta misma obra comienza con una definición que ubica al autor entre los pioneros de la temática que se investiga en el presente trabajo: "Un diálogo es ante todo un problema de interculturalidad. La distancia física que separa a los interlocutores y las vueltas retóricas para entenderse, refieren a un problema cultural" (KUSCH, 1987, p. 13).
}

\begin{tabular}{c|c|c|c}
\hline Rev. Ciências Humanas & Frederico Westphalen, RS & Pg. 63-83 & Maio/Agosto 2019 \\
\hline \multicolumn{2}{c|}{ Recebido em: 26/05/2019 } & Aceito em: 16/09/2019 \\
\hline
\end{tabular}




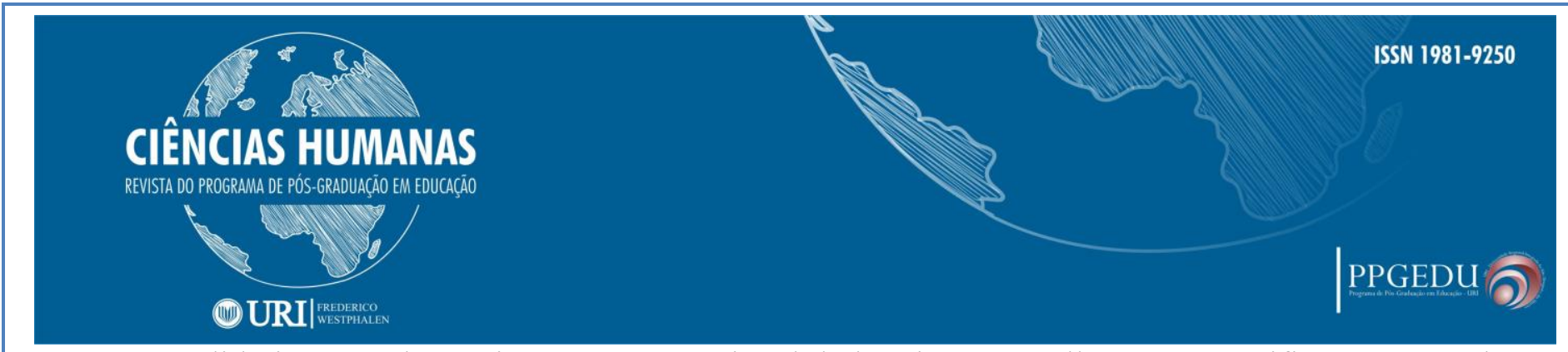

solidarizan con la versión más convencional de la misma, aquella que se manifiesta como "el orden regulador" de la convivencia o la expresión que encierra en sí la medida absoluta de lo humano. La universalidad transformadora de la filosofía, en cambio, está constituida en base al diálogo entre universos contextuales. No se encierra como aquella en un nosotros que envuelve al otro en un yo de rango superior. Se parece más a una corriente de alteridades que se atraen, en la misma medida que se absuelven de todo englobamiento. Esta atracción, no obstante, no es sólo deseo sino además trabajo, esfuerzo y amplitud en ese nivel del lenguaje que se articula a la vida concreta: esfuerzo de traducción. Los universos culturales se traducen "y traduciéndose unos a otros van generando universalidad" (FORNET-BETANCOURT, 2003, p. 19). Se subraya la palabra "esfuerzo", como el ejercicio ético de una voluntad convocada a descentrarse del nicho egoísta; ya que no se trata de la mera referencia a un oficio o actividad técnica. Consideramos que el motor de esa "escuela de traducción" metáfora que Fornet-Betancourt elige para referirse a la transformación estructural de la universalidad- es ante todo un "deseo ético" que, como enseña Levinas, desborda la ontología, en franca dirección hacia la experiencia de lo extranjero.

Sostendré entonces que la transposición didáctica, es decir, el conjunto de mediaciones que enlazan el saber "sabio" -académico, científico- al saber enseñado y aprendido, debe comprenderse a partir del modelo de la traducción ${ }^{4}$. Esta comprensión permitirá pasar de un esquema reproductivista a una dinámica dialógica, iluminando el carácter intrínsecamente ético de la educación, concebida como práctica de la hospitalidad entre diferentes cosmovisiones y formas de vida. Dicho en otras palabras, sostengo la hipótesis de que el modelo didáctico de la transposición en el marco de una pedagógica intercultural debe ser remitido a la esfera de la traducción, tal como ésta aparece en las versiones de filósofos tales como Fornet-Betancourt, Benjamin o Ricoeur, sin pasar por alto las diferencias que puedan separar a estos pensadores. Considero que esta inclusión es central en la educación en valores

\footnotetext{
${ }^{4}$ Sobre la relación entre "traducción” y "transposición” constituye un aporte de especial relevancia la referencia que hace J. Larrosa, cuando reflexiona sobre el modelo de la traducción según H. G. Gadamer. Larrosa, partiendo de distinciones gadamerianas, refiere a la imaginería clásica acerca del término "traducción" (traducere) que remite al "transporte", la "traslación" o el "traslado". A los fines de este trabajo es importante señalar el parentesco de sentido que revela el texto de Larrosa: "traducción en alemán es Übersetzung, un calco semántico del compuesto latino trans-positio, de donde deriva transposición, pero también un calco semántico del compuesto griego meta-phorein, que todavía en el griego significa transporte” (LARROSA, 2003, p. 18).
} 


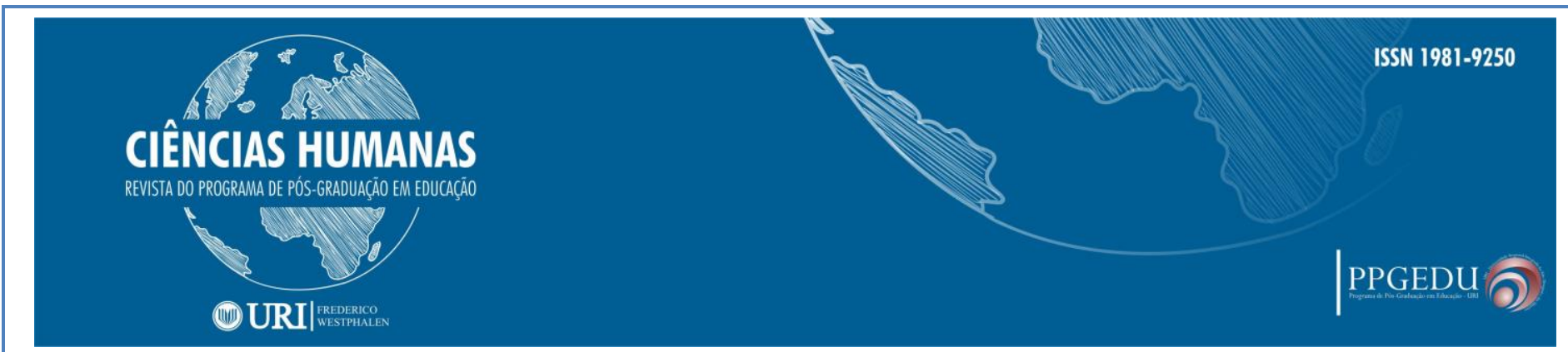

y la formación ética y ciudadana, dado que ella permite en sí misma visualizar, más allá de los neutralismos tecnicistas, el espíritu ético y pluralista que anida en todo acto verdaderamente educativo.

En lo que sigue, se abordará el modelo de la traducción de acuerdo con los enfoques de Walter Benjamin (1982) y, sobre todo, de Paul Ricoeur (1996, 2000, 2005), ambos en clave filosófica. Dichas reflexiones serán confrontadas con el modelo de la transposición didáctica de Chevallard, para pasar luego a examinarse el abordaje intercultural de ciertos problemas específicos de la ética. En el marco crítico de los dispositivos pedagógicos se resaltará la importancia de los estudios postcoloniales y los enfoques de autores como Levinas y Derrida. Se concluirá, en base al análisis crítico de textos de Fornet Betancourt y Salas Astrain ${ }^{5}$, con una serie de ideas a modo de aportes para una práctica educativa intercultural.

\section{DE W. BENJAMIN A P. RICOEUR}

Si el acto de traducir significara reproducir en la lengua destinataria lo mismo que un autor dice en su lengua, la traducción sería un fenómeno técnico de escaso valor para los estudios interculturales. Eso "mismo", objeto de referencia y transposición de un plano a otro, habitaría en el universo inconmovible de un lenguaje de esencias, que haría explícita las equivalencias de los distintos fonemas, desestimando las contingencias particulares de cada alojamiento lingüístico.

Para eludir esta especie de regresión a las aporías del platonismo puede rastrearse el meollo de la traducción, allí donde el esquema de la equivalencia resulta menos convincente: en el contexto de las producciones artísticas. Dicha región de dudosa traducibilidad es el punto de apoyo de Walter Benjamin, en su estudio La tarea del traductor. La obra de arte no hace un uso instrumental del lenguaje como código para comunicar o informar a un receptor una determinada idea. El arte se despreocupa de la recepción en la medida en que sus modalidades referenciales se subordinan siempre a la función poética o expresiva. En cambio, en toda locución que sirve al propósito de informar, el dato adquiere especial inmunidad y es fácilmente trasladable de una lengua a otra. Por lo tanto, el traductor de arte que pretenda

\footnotetext{
${ }^{5}$ Filósofo Chileno que, como se verá, incursiona en los alcances de la ética discursiva en el contexto de la filosofía intercultural. (SALAS ASTRAIN, 2003).

\begin{tabular}{l|c|c|c}
\hline Rev. Ciências Humanas & Frederico Westphalen, RS & Pg. 63-83 & Maio/Agosto 2019 \\
\hline
\end{tabular}

\begin{tabular}{l|l} 
Recebido em: 26/05/2019 & Aceito em: 16/09/2019
\end{tabular}
}




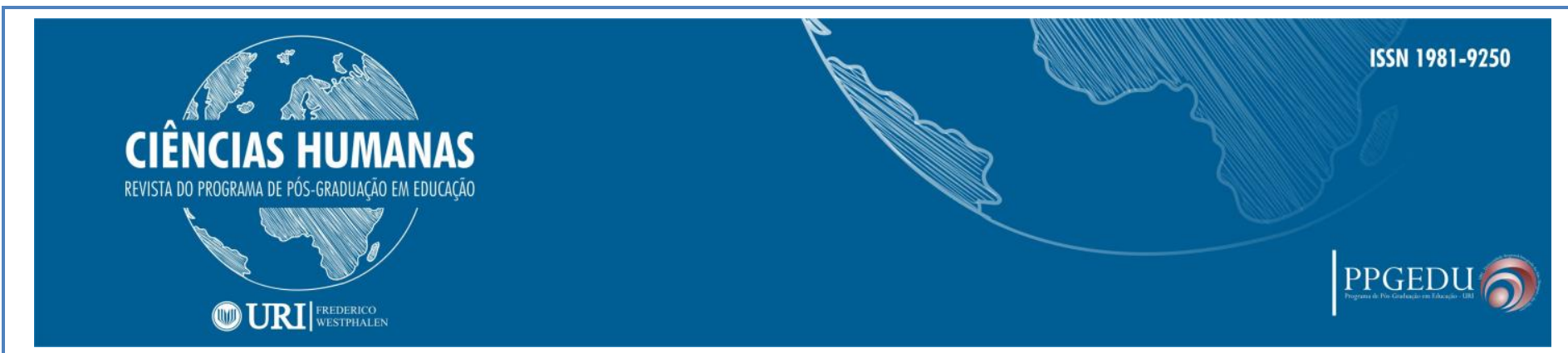

brindar un servicio al lector decodificando su contenido "sólo podría transmitir una comunicación, es decir, algo que carece de importancia” (BENJAMIN, 1971, p. 127), en suma, una "mala traducción".

El original no está destinado al lector, subraya Benjamin (1971), y en esta indiferencia por el ser humano en tanto receptor reside su no indiferencia por el "carácter físico y espiritual del hombre". Puede considerarse, entonces, que eso "intangible, secreto, poético" constituye la particularidad del arte; situación que lo exceptúa de la comunicabilidad propia de las restantes manifestaciones de la lengua. Sin embargo, si, lejos de encasillar el lenguaje en un rol meramente instrumental, lo descubrimos en su viva articulación con la cultura, advertiremos que el intercambio consciente de mensajes sucede solo en la "superficie" de las formas de vida.

Contra la interpretación de la lengua como "medio" para la repetición de las ideas de un original, Benjamin sostiene un "parentesco idiomático" o vínculo íntimo de éstas, que atrae los servicios de toda buena traducción: "la traducción sirve pues para poner de relieve la íntima relación que guardan los idiomas entre sí" (BENJAMIN, 1971, p. 131). Se trata de un parentesco, más allá de toda semejanza o analogía "en la estructura de dos frases" (1971, p. 138); relación que se funda en el hecho de que ninguna lengua puede existir por separado. Ninguna lengua es fruto de, ni sobrevive a su aislamiento, como tampoco ningún hombre ni cultura. Por lo tanto, palabras, sujetos y mundos, convergen en la búsqueda de un lenguaje perfecto, ideal. Entendemos que esta "carencia” idiomática, gobernada por una especial atracción hacia la unidad y la perfección, tiene tanto de búsqueda y de rescate como de pérdida. Todo el escrito de Benjamin gira en torno a la consideración de perspectivas complementarias más que de campos superpuestos. Pero la idea de "complemento" no debería concebirse en el marco de un engranaje u orden completo y sin aberturas. Más bien, la revelación de todo texto traducido se encuentra a mitad de camino entre la repetición de lo mismo en otro idioma y aquello escurridizo a toda reproducción que permanece en la intangible zona del silencio y el misterio: agrega un sentido nuevo al original.

Encontramos en el texto de Ricoeur demasiadas similitudes con el de Benjamin, menos barroco el del filósofo francés y con el acento puesto sobre la advertencia de la renuncia al ideal. No se trata de ceñirse al sueño profético de una lengua perfecta, sino de 


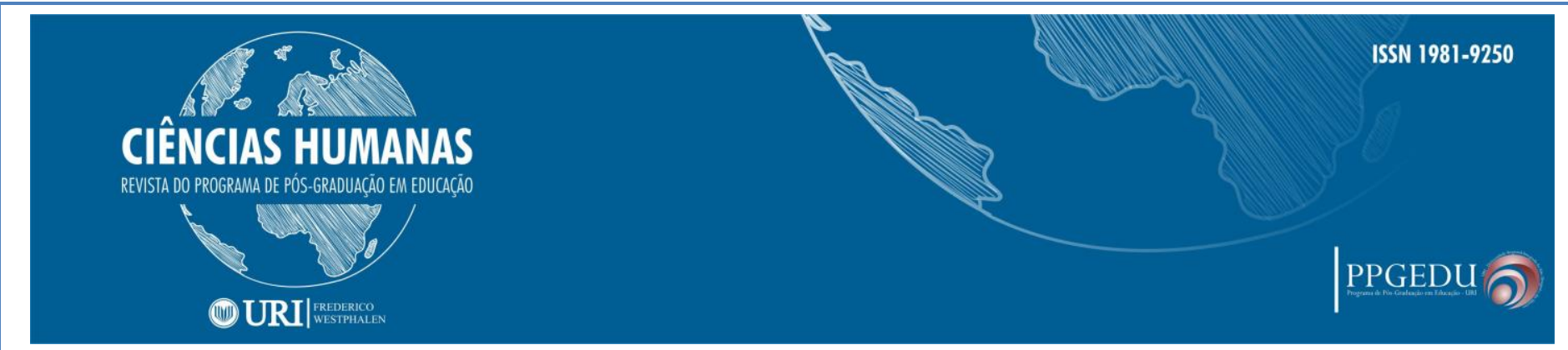

asumir la radical imposibilidad de su realización y abrir un campo de reflexión a partir de ese "duelo". Ricoeur invita a entender esta laboriosa actividad de acuerdo con la distinción freudiana entre "trabajo del recuerdo" y "trabajo del duelo" (RICOEUR, 2005, p. 19). Se destaca primero ese particular papel de mediador, que somete al traductor al incómodo tironeo de dos amos que lo requieren para sí: por un lado el autor y su obra, por el otro, el lector.

La resistencia que eleva la psiquis ante la fuerza liberadora del recuerdo es comparada con una doble tensión: la del texto a traducir -la siempre ostentosa originalidad que desmorona anímicamente al traductor- y la de la lengua receptora de la traducción. En este caso, suele interponerse una pretendida autosuficiencia, que disimula el miedo narcisista a las "heridas" que puede abrir lo extranjero. La ilusión que aporta una salida provisoria de estos enredos consiste en postular una "lengua perfecta", capaz de limar las diferencias que separan un texto del otro. Sin embargo, ese "tercer texto" es decir, aquella "mismidad" capaz de oficiar de patrón de medida entre la lengua de partida y la lengua de llegada no existe más que como una abstracción, que reduce toda la riqueza del lenguaje a su delgada capa informativa. Toda traducción está acosada por el fantasma del duplicado. No obstante, no hay reproducción que no exprese la diferencia en el doble juego de la conquista y la pérdida.

Según Ricoeur, entre dos lenguas no hay superposición total de campos semánticos, las sintaxis no son equivalentes y las relaciones culturales que articulan son siempre asimétricas. Entonces, uno de los modos más sensatos de doblegar las resistencias de la traducción es entregarse a un "trabajo de duelo" consistente en "renunciar al ideal de la traducción perfecta" (RICOEUR, 2005, p. 25). Según Ricoeur, semejante sueño consiste en una pretendida "ganancia sin perdidas", ante lo cual es necesario elaborar un "duelo" hasta "la aceptación de la diferencia insuperable de lo propio y lo extranjero" (RICOEUR, 2005, p. 27). Esta disposición capaz de combinar lo entrañable y lo extraño, lo atrapable y lo esquivo, la igualdad y la diferencia, sugiere ya una "ética" en la traducción, mucho antes de que la ética asuma el perfil disciplinar de los formatos curriculares. Hay en todo acto de traducir un "dar cabida" al otro, que impide su "adecuación" o "absorción". El diálogo es la compensación que se obtiene a cambio de la pérdida del "absoluto lingüístico"; se trata de una apertura de mundo que Ricoeur denomina "hospitalidad lingüística” (RICOEUR, 2005, p.28). 


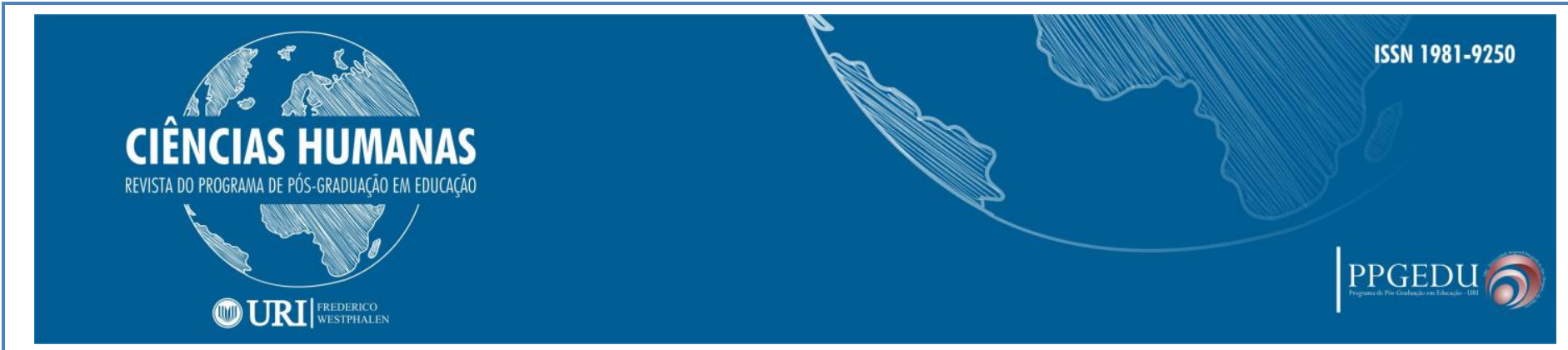

El "sueño ilustrado", o mito de una lengua perfecta que remite siempre a un arquetipo monocultural, comienza a mostrarse obsoleto ante el despuntar de un "nuevo tipo" de universalidad basado en el modelo de la traducción. Ya se aprendió de éste a renunciar a la traducción perfecta; esta resignación también propicia el duelo ante el derrumbe de toda "universalidad" que pretenda erigirse en "norma" sin atender a la contextualidad de cada caso particular. De acuerdo con estas coincidencias, se ha destacado el pasaje que Ricoeur dedica al debate sobre la universalidad, ahora en el marco del modelo de la traducción. O bien la heterogeneidad radical de las lenguas vuelve la traducción teóricamente imposible, o bien su viabilidad "se explica mediante un fondo común que vuelve posible el hecho de la traducción" (RICOEUR, 2005, p. 35). La alternativa "traducible versus intraducible" guarda un notorio paralelismo con aquella que fuera analizada más arriba, de acuerdo con la fórmula universalismo versus relativismo, en el plano de la enseñanza de la ética. En todos los casos se trata de superar algo así como esa tensión que Ricoeur señala entre el "formalismo de gabinete" y el "relativismo de campo" (RICOEUR, 2005, p. 41).

Con la caída de la universalidad ilustrada -una especie de "torre de Babel"- el yo gana para sí la consideración de "lo otro" como algo constitutivo de su mismidad. De ahí que Ricoeur esté tan interesado no sólo en lo extraño de la lengua extranjera, sino, especialmente, en aquello extranjero de la lengua propia. La ganancia en cuestión es un hallazgo de orden antropológico: la condición del hombre es, para decirlo evocando la obra de Steiner, un “después de Babel” (STEINER, 2001, p. 13) ${ }^{6}$. La existencia dispersa y confusa del viviente humano, el desmoronamiento y la diseminación a la que se refiere el relato del Génesis, lejos de inspirar un sentimiento de recriminación o castigo, se manifiesta como experiencia que nos libera del monólogo, en dirección de una auténtica proximidad (RICOEUR, 2005, p. 58); dicho en las coincidentes palabras de Larrosa:

[...] La confusión y la dispersión babélica no es sólo esa pluralidad casi infinita de lenguas y de variantes de lenguas. Babel quiere decir también, y sobre todo, que la lengua, cualquier lengua, en cualquier momento de su historia y en cualquier

\footnotetext{
${ }^{6}$ Después de Babel, en palabras de su autor: “(...) postula que la traducción está implicada formal y pragmáticamente en cada acto de comunicación, en la emisión y en la recepción de todas y cada una de las modalidades del significado, ya sea en el sentido semiótico más amplio o en los intercambios verbales más específicos (...) La traducción de diferentes lenguas es una instancia particular en una configuración y modelo fundamental para el habla humana, aunque esta fuera monoglota” (STEINER, 2001, p. 3).
}

\begin{tabular}{c|c|c|c}
\hline Rev. Ciências Humanas & Frederico Westphalen, RS & Pg. 63-83 & Maio/Agosto 2019 \\
\hline \multicolumn{2}{c}{ Recebido em: 26/05/2019 } & Aceito em: 16/09/2019 \\
\hline
\end{tabular}




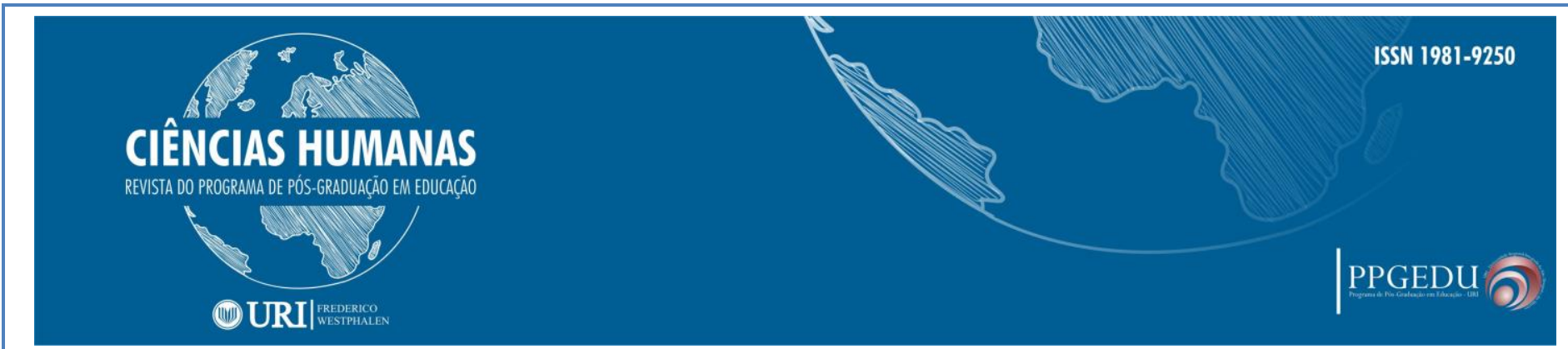

contexto de uso, se da en estado de confusión, en estado de dispersión; Babel significa que la palabra humana se da como confusa, como dispersa, como inestable y, por lo tanto, como infinita. (LARROSA, 2003, p. 84).

Hay, no obstante, argumentos que rechazan el encuentro de lo propio y lo extranjero, en nombre de un "humanismo" unidimensional -"anti-babélico" diría Larrosa- que subestima las diferencias entre los distintos mundos de la vida. Ingenua o tendenciosamente, se alzan las banderas de un cosmopolitismo, entre tecnológico e ideológico, bajo el exitoso término de "globalización". Los motes de "trascendental" o "planetario" vuelven a encubrir lo que a menudo no satisface más que a un puñado de intereses particulares. ¿No debería apostarse a un humanismo -auténtico- para el cual la heterogeneidad sea la condición misma del encuentro interhumano y del lazo ecológico entre seres humanos y naturaleza? ¿Puede la metáfora de la traducción asistir al recopilado de mundos, aún aislados en la versión posmoderna del diferendo y la inconmensurabilidad? Pueden ofrecerse variadas descripciones de esta convergencia de ribetes paradójicos: "equivalencia presunta" o "no fundada en una identidad de sentido demostrable" son algunas de las pistas semánticas que Ricoeur adopta para referirse a la traducción. Mediante ella se ejercita una "fidelidad" nutrida de permanentes desfasajes que, proyectados sus efectos al contexto intercultural, rompe con el mito de la "inconmensurabilidad" en camino de una "construcción de comparables" en común (RICOEUR, 2005, p. 75).

En varias de sus obras Ricoeur distingue entre discurso y sistema de la lengua. Este último "es virtual y se halla fuera del tiempo" (RICOEUR, 2000, p. 170). Otro rasgo de la diferenciación es la importancia de quién habla para el discurso; la lengua, en cambio, carece de sujeto. Además, la lengua prescinde de "mundo", de referente, que se pretenda describir, exhibiendo siempre la estructura de un "código" al servicio de la comunicación. No es este concepto de "lengua" como "sistema" el animador de su caracterización bajo el signo de la "hospitalidad", sino el de la lengua viviente encarnada en producciones históricas y culturales. También hay una transposición muy particular en la traducción a esa "palabra viva" de aquellos contenidos provenientes del lenguaje escrito y los escritos "de autor". Podríamos considerar cierta apertura del diálogo al alojamiento de contenidos inscriptos y fijados por la experiencia de la lecto-escritura. Nuevamente estamos ante un caso de posible equivalencia sin adecuación. La palabra viva es fugaz y supone la intención de un hablante, en cambio 


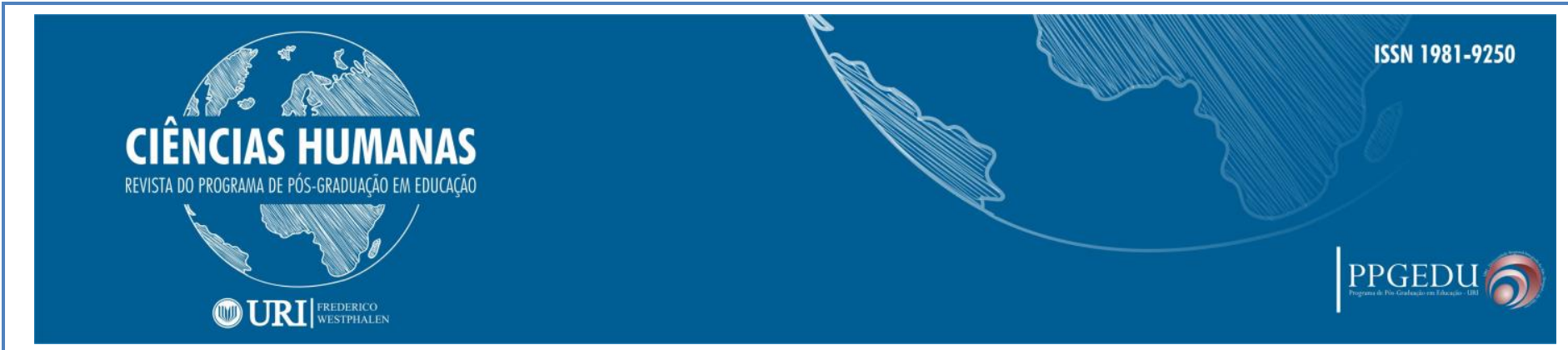

dicho en palabras de Ricoeur: "la carrera del texto escrito se sustrae al horizonte finito vivido por el autor" (RICOEUR, 2000, p. 173). En el discurso oral el lecto-acontecimiento se ve siempre superado por la referencia a un "mundo en común" entre los interlocutores. El texto, en cambio, proyecta un mundo que no es un mundo situado: "libera a su referencia de los límites de la referencia ostensiva" (RICOEUR, 2000, p. 174). Se debería renunciar, una vez más, a la traducción perfecta (trascendental) de lo escrito al lenguaje hablado, hecho que, como toda explosión de alteridad (todo "después de Babel"), enriquece la exposición y permite la construcción de comparables entre lo leído y lo vivido ${ }^{7}$.

\section{TRANSPOSICIÓN Y TRADUCCIÓN}

El pensamiento de Chevallard alienta un enfoque más bien sistémico. Parte del concepto de "sistema didáctico" y analiza su constitución tripartita, que evoca el modelo de la traducción. Aquí la embarazosa situación del traductor que, según se vio, estaba a merced de "dos amos", se traslada a la tarea del docente que, a grandes rasgos, debe satisfacer por un lado a los alumnos (y su entorno) y, por el otro, a ese complejo sistema que denominamos "saber". El saber, según Chevallard (1991, p. 15), es un tercero "curiosamente olvidado" que reclama su derecho a ser incluido en todo debate serio sobre las relaciones educativas. De este modo, el desafío que el saber, concebido en su carácter de "enseñado", abre a la teoría de la transposición apunta a la relación que éste guarda con lo que "se proclama de él fuera del ámbito educativo" (CHEVALLARD,1991, p.15), es decir, con el "saber sabio" que pretende exhibir la presunta objetividad del objeto. Por lo tanto, siguiendo la caracterización de Chevallard, el concepto de transposición didáctica remite "al paso del saber sabio al saber enseñado" y a la distancia eventual y "obligatoria" que los separa. Con la alusión a una diferencia que asume el carácter de lo obligatorio se está queriendo significar la imposible superposición de los campos en cuestión. Que dicha asincronía opere como herramienta útil a la labor del didacta depende de la conciencia de su necesidad. Este acierto corrige la creencia

\footnotetext{
${ }^{7} \mathrm{Al}$ respecto también cabe citar la interesante descripción que efectúa Carlos Skliar y que abona lo que se viene señalando en función de una interpretación progresiva y alteritaria del relato de Babel: “( ...) puede nombrar todo lo que es extranjero, la condición humana misma como extranjeridad. Y con eso puede contribuir a reformular un viejo motivo, el de la existencia misma como exilio, pero ahora más radicalmente: como un exilio constitutivo, inevitable, sin remedio" (SKLIAR, 2011, p. 47).
}

\begin{tabular}{l|l|l|l}
\hline Rev. Ciências Humanas & Frederico Westphalen, RS & Pg. 63-83 & Maio/Agosto 2019 \\
\hline
\end{tabular}

\begin{tabular}{l|l} 
Recebido em: 26/05/2019 & Aceito em: 16/09/2019
\end{tabular}




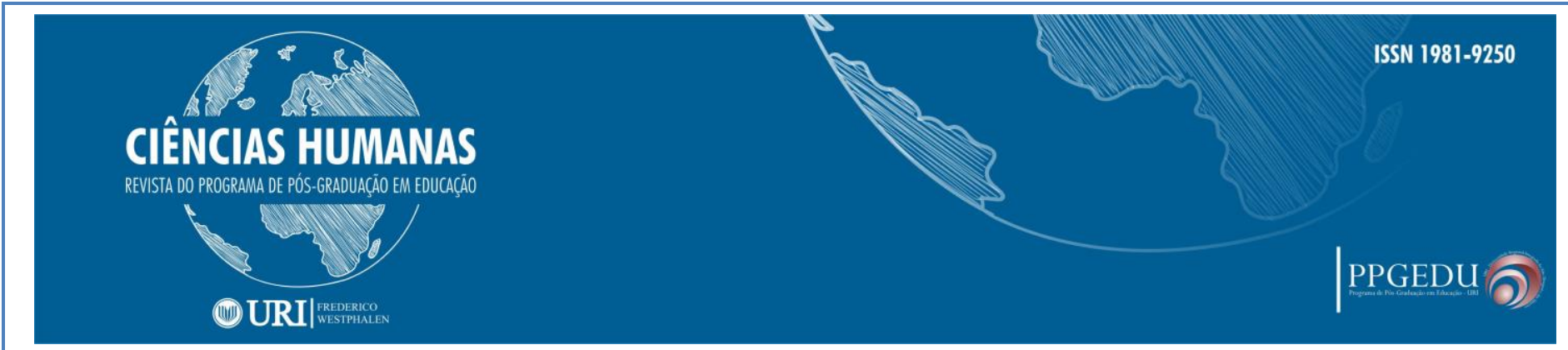

siempre engañosa de la perfecta correspondencia entre lo que se enseña y el objeto enseñado y permite la "ruptura" que la didáctica debe ejercer para constituir su dominio propio (CHEVALARD, 1991, p. 16). Sin embargo, lo común de la cultura institucional es basar su credibilidad en el aliento de esa "ficción de identidad" que no asume la "deformación" del contenido abordado. Se reedita en este campo el mismo concepto freudiano de "resistencia" del que supo valerse Ricoeur en su análisis del modelo de la traducción. Hay, según Chevallard, una resistencia institucional a enfrentarse a esa brecha que delata la ficción de identidad. El culto a la perfección y la transparencia de contenidos, similar al sueño de una lengua perfecta, se aferra a la ilusión de la reproducción de un texto que elimine toda impureza proveniente del contexto. Al menos en los momentos de "normalidad" las instituciones se relacionan con la sociedad en base a esta engañosa autosuficiencia. Ella suele oficiar como garante de la supervivencia del sistema didáctico, reforzando la compatibilidad con el entorno social. De este modo, el saber transcurre "exiliado de sus orígenes" (CHEVALLARD, 1991, p. 21) y su contexto de producción histórica, en la tranquila naturalidad que le imprime la atmósfera escolar. Pero la distancia subyacente entre el análisis epistemológico y el marco didáctico no tarda en promover una serie de malestares que alteran el debido equilibrio. Aparecen grietas, donde las adopciones hechas por el sistema educativo desnudan esa ausencia de superposición de registros, y se hace necesario revitalizar los flujos de intercambio entre ciencia, sociedad y pedagogía.

El comando de especialistas, que desde el interior mismo del sistema didáctico se hace cargo de estos ajustes es denominado por Chevallard "noosfera" (CHEVALLARD, 1991, p. 28). Pero ¿en qué consiste la crisis? Puede asociársela a un fenómeno particular de la entropía. El espacio insalvable que separa a uno y otro saber se ensancha peligrosamente. Los contenidos didácticos inician un curso regresivo que amenaza disolverlos en el sentido común, envejecimiento reforzado por la vertiginosa y ascendente carrera de la ciencia y la técnica. Las familias de los alumnos reaccionan contra el arcaísmo y la disfuncionalidad de contenidos, mientras que los expertos abonan dichas quejas con la divulgación de adelantos teóricos y técnicos que descolocan la oferta del sistema escolar. La comunidad didáctica (noosfera) se ve entonces impelida a ensayar "retoques" capaces de acortar la distancia con el saber sabio y "poner a distancia" a los padres. 


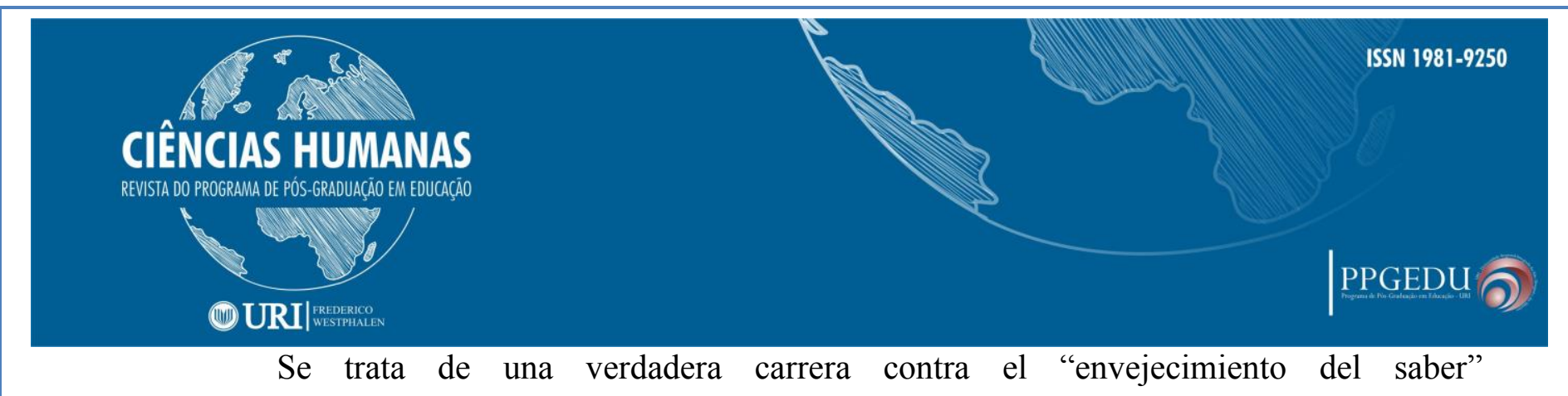

(CHEVALLARD, 1991). Este notable esfuerzo no deja de estar atravesado por una particular sensación de duelo. En efecto, Chevallard señala algo así como la presencia nouménica de un horizonte de conocimiento, al que los contenidos transpuestos de la experiencia educativa nunca pueden reproducir con exactitud. No puede superarse el límite de una réplica siempre condicionada a su enseñanza, como si se tratara de la imitación defectuosa con que lo sensible participa de una idea platónica. Esta añoranza de la exactitud no está demás, sobre todo, si se entiende que los estudios de Chevallard fueron efectuados en el marco de una reflexión sobre la didáctica de las matemáticas. En el campo de la formación ética y ciudadana, en cambio, eso que se denomina "duelo" adquiere un sentido y alcance diferente. Por lo pronto, el valor de asumir la imposible adecuación entre un original y un derivado, renuncia compatible con la de la "universalidad ilustrada" y la de la "lengua perfecta", lejos de desencadenar una aproximación -siempre sombría- al presunto ideal, contribuye a enriquecer el saber con aquella sabiduría proveniente la interpretación y la crítica, en una auténtica comunidad de sujetos activos. Este universo dialógico, obtenido en compensación del abandono de absolutos lingüísticos y educativos, lejos de decretar la imposibilidad de enseñar, alienta una transformación (filosófica) de la educación, donde el "saber" se emancipa definitivamente del "repetir". La ya aludida "experiencia de lo extranjero en la propia lengua" es el motor de dicha transformación que representa una ética -como expresión de humildad y deposición narcisista- inherente al acto mismo de educar, más allá de sus programas y sus métodos.

La renuncia a la mera reproducción de paradigmas de "alta cultura" puede dar lugar a esa ganancia de sentido que aporta la articulación de la cotidianidad en base al diálogo y la interpretación. Los espacios de interculturalidad en la propia lengua que pueden abrirse a partir de la "simbiosis" entre academia y sociedad son de vital importancia para la articulación entre ética y ciudadanía. Constituyen el polo virtuoso de una transposición que enriquece el saber de gabinete, lanzándolo a un escenario de múltiples horizontes y revalidación permanente de prácticas y conocimientos. En todo caso, los contenidos éticos "envejecen" o se debilitan, cuando se desautoriza el rol interpretativo o se abandona la postura crítica frente al orden instituido, y se los convierte en meras herramientas de socialización o adaptación. 


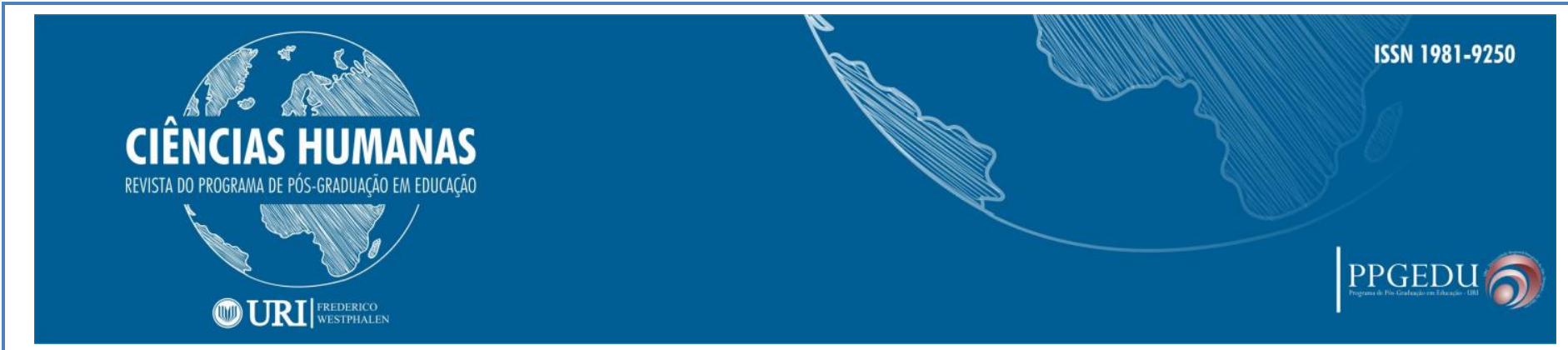

Por lo tanto, y enlazando a Fornet-Betancourt y Paulo Freire en un mismo concepto, la educación ética es más una "zona de traducción" que una zona de "transferencia" de contenidos $^{8}$. En una pedagógica intercultural las dinámicas de transferencia existen siempre en función de las dinámicas de traducción. Lo dicho significa, para dar un ejemplo, que es indispensable un Kant bien transferido, es decir, "adecuado" y conforme a las versiones más prestigiosas, pero no para quedarse en la celebración (erudita) de dicho conjunto de datos, sino para dar lugar, a partir del mismo, a la labor crítico-interpretativa que crece en esos espacios de imposible adecuación. Es notorio que bajo esta orientación el maestro también aprenda del alumno, y que el conocimiento, tal como señala Freire, se construya en una comunidad de diálogo. Si, por el contrario, se abstrae el proceso educativo de la influencia rectora del modelo de la traducción, nos quedamos con el modelo de la explicación y la adecuación explanans-explanandum, que minimiza la relevancia de la palabra como acto creador de sentido.

\section{LA COMUNIDAD POST-BABEL}

Ya entre sujetos de una misma cultura se ha denunciado razonablemente la llamada "colonización pedagógica", hecho que muestra a los intelectuales de la "alta cultura" organizando el saber de los educandos en base a paradigmas extranjerizantes y al servicio de un orden excluyente. La sospecha recrudece y gana en complejidad cuando la autoridad pedagógica se halla en manos de docentes de una cultura nacional, que intentan formar al extranjero o a los sujetos de comunidades preexistentes al orden estatal.

Las distinciones suelen expresarse en binarismos que enturbian la comprensión de lo que llamamos "interculturalidad". Muchos de los sectores indóciles, ante estas renovadas catequizaciones, suelen comportarse en dirección opuesta, aunque funcional. Hommi Bhabha, en la senda de F. Fanon, destaca la complicidad que anuda a dominadores y dominados, permitiendo a éstos últimos "el sueño de la inversión de papeles" (BHABHA, 2002, p. 61). De todos modos, la conciencia del excluido está siempre a un paso de trascender esa “identidad funcional”, forjada bajo la lógica del discurso opresor. Lo verdaderamente negado

\footnotetext{
${ }^{8}$ Dicho en palabras del propio Freire: “[...] Enseñar no es transferir conocimiento sino crear las posibilidades para su propia construcción o producción” (FREIRE, 1997, p.47). \begin{tabular}{l|c|c|c} 
Rev. Ciências Humanas & Frederico Westphalen, RS & Pg. 63-83 & Maio/Agosto 2019 \\
\hline
\end{tabular} \begin{tabular}{l|l} 
Recebido em: 26/05/2019 & Aceito em: 16/09/2019
\end{tabular}
} 


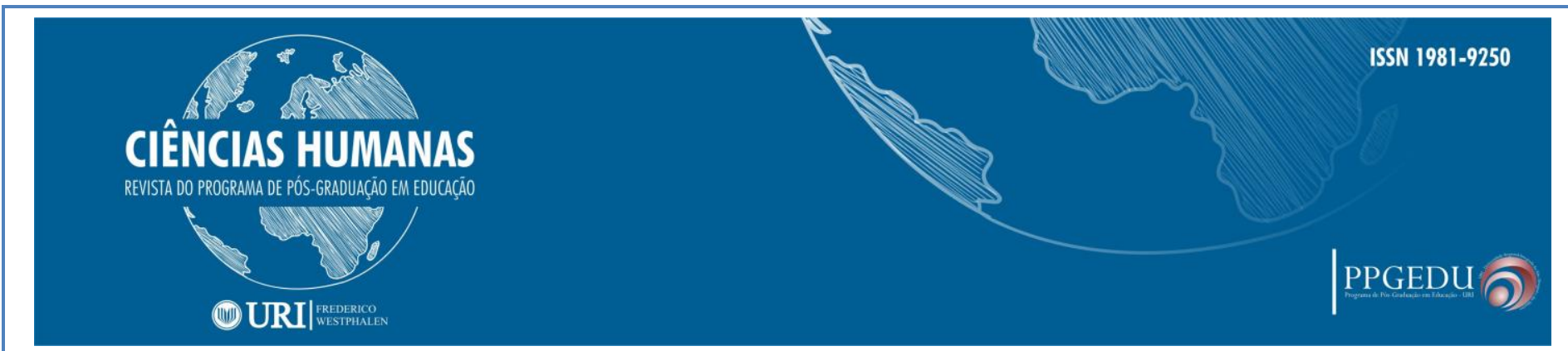

en toda dominación es lo intersticial, esa estancia de la (inter)subjetividad simbolizada como un "después de Babel". Por lo tanto, una educación ética post-Babel no puede favorecer la implantación de un modelo "global" de ciudadano, pues ello conduciría a la arbitraria reducción de las notas particulares que distinguen a los diversos "humanismos"; pero tampoco puede mostrarse complaciente o inactiva ante los crímenes o humillaciones que pretendan ampararse en el relativismo cultural.

Hablar de un "post-Babel" no significa, por tanto, deambular en un ruinoso paisaje de mundos desperdigados, sino adherir al replanteo del concepto de comunidad, asumiendo que lo "común" característico de la proximidad entre humanos debe saber cobijar la extrañeza y la discontinuidad, sin encerrarse en la uniformidad y la monotonía ${ }^{9}$. Esto conduce a una posible advertencia sobre el prefijo "inter". Ha de entenderse que no se trata de un mero conector de naturalezas homogéneas, como el cemento que sirve de juntura a las piezas de un mosaico. Más bien, el "inter" que denota relación con otro "hacia afuera" está también señalizando esa constitución tan paradojal y heterogénea del mundo propio. De ahí que "originariedad" no debería confundirse con "impermeabilidad", ni el "nosotros" debería encarnar la pretensión de una "pureza" impenetrable. A propósito, Derrida, un filósofo tan expuesto a ser encasillado como relativista, es particularmente eficaz a la hora de arrimar "fundamentos" a una interculturalidad que también puede exhibir gustosa el título de "alter-culturalidad". ¿De qué otro modo entender esa sutil enseñanza a la que el filósofo no se cansa de volver, en el medio de párrafos trabajosos y barrocos, eso de que "tan sólo se habla la lengua del otro"?

La imposición de una lengua, como la de una cultura, es siempre una impostura que descansa sobre la pretenciosa titularidad de un "bien" fatalmente esquivo a todo registro de propiedad. La lengua es un constituyente escurridizo a la posesión del hablante. De ahí que enseñar una lengua sea, mucho más, una opción a compartir lo que en el fondo "no se tiene", que habilitar a otro para una presunta "prolongación" o "implante" de lo propio. No obstante, la advertencia de este "exilio" o esta "nostalgia", que nos une irremediablemente a una "lengua materna" (DERRIDA, 1997, p. 82) o a un "origen", no debe llevar a la confusión de que todos los exilios son equivalentes. No, la expatriación forzada por el dominador es bien distinta; es el amargo fruto, justamente, de la inconsciencia de quienes en su delirio de

\footnotetext{
${ }^{9}$ Una comunidad es también "plus d'une communauté", en el sentido de que "es siempre más y otra cosa que ella misma" (LARROSA, 2003, p. 101). 


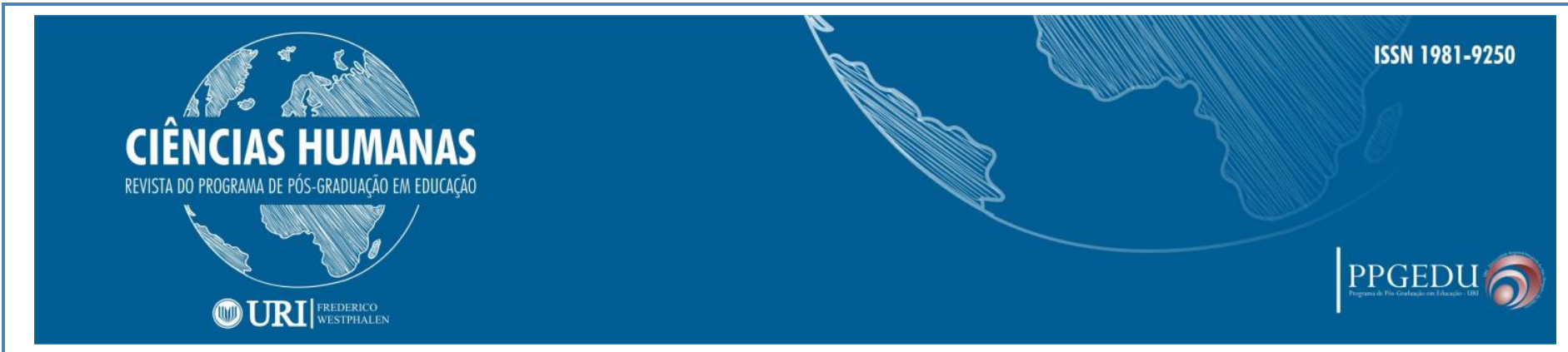

grandeza se sienten dueños de la lengua o de la cultura; es decir, de aquellos que no asumen la condición "post-Babel”. A través de cuidadosos sondeos autobiográficos, Derrida deja al descubierto las marcas irreversibles de dichos dos exilios. Como judío nacido en Argelia bajo la ocupación francesa su "hablar materno no tiene verdaderamente la unidad, la edad y la proximidad supuesta de un hablar materno, habida cuenta de que ya es la lengua del otro, del colono francés no judío" (DERRIDA, 1997, p. 104). En el citado pasaje el "otro" es el "dueño" de la lengua y la cultura oficial: "el colono francés no judío", es decir, el representante del sector dominante. De todos modos, esta sujeción a la alteridad hegemónica de un modelo colonial revela a la víctima -Derrida en este caso- la estructura universal que esconde esta situación en apariencia excepcional. Se trata, como dice Derrida, de una especie de "alienación originaria que instituye a toda lengua como lengua del otro: la imposible propiedad de una lengua" (DERRIDA, 1997, p. 82). Aquí la alteridad ya no es la de un "otro" que intenta a través de la guerra o la política expandir e imponer su mismidad, sino la del otro vulnerable a toda estructura cerrada y expansiva; la de quien encarna ese "fondo" frágil e indócil, impredecible e inapropiable ${ }^{10}$, de lo auténticamente humano. Como se advierte, no se está ya ante la disyuntiva entre lo que es "propio" y lo que se quiere imponer desde "afuera"; no estamos ante la interdicción o la represión que un dispositivo pedagógico ejerce sobre un conjunto de pertenencias o fijaciones autóctonas. La transposición colonial del conocimiento que no aparece en el texto de Chevallard, como tampoco aparece ninguna referencia a políticas de la lengua o la cultura- falsea la historia y niega relevancia a las producciones locales y los hallazgos originales. Para ella "lo otro" no es un valor constitutivo de la subjetividad sino, más bien, el lujo opcional de sujetos excéntricos o exóticos. Sin embargo, lo negado por la celebración de ese supuesto "saber sabio" -a cuya reproducción y fichado erudito la academia llama "seriedad"- resurgirá en la traducción enriquecedora de textos que efectúe una verdadera comunidad crítico-dialógica. No hace falta a esta altura agregar que se trata de una forma de koinonía donde la pertenencia no gira alrededor de un núcleo sustancial: una comunidad post-Babel.

\footnotetext{
${ }^{10}$ También puede apreciarse en la lectura de la citada obra de Steiner una recurrente referencia a este aspecto intangible de toda lengua. Su constitución fluye, emancipada de los designios del hombre: “[...] como el modelo más sobresaliente del principio de Heráclito. Se altera en todo momento del tiempo vivido. La totalidad de los acontecimientos lingüísticos no sólo aumenta, también es calificada por cada nuevo acontecimiento. Y en una sucesión temporal, no hay dos afirmaciones que sean perfectamente idénticas" (STEINER, 2001, p. 40).
}

\begin{tabular}{l|c|c|c}
\hline Rev. Ciências Humanas & Frederico Westphalen, RS & Pg. 63-83 & Maio/Agosto 2019 \\
\hline
\end{tabular} 


\section{CONSIDERACIONES FINALES}

¿Por qué pensar, entonces, la trasposición didáctica bajo la forma de la traducción, y por qué pensarla así en el marco ya no de una mera facticidad intercultural, sino de la interculturalidad como reclamo (ético-político)? Se ha visto que la trasposición es el proceso que describe el pasaje del supuesto "saber sabio", ese que produce la comunidad científica, al saber que se transmite en el aula. Los contenidos áulicos están sujetos a la repetición, al desgaste $y$, por lo tanto, a un "envejecimiento" que habría que combatir ajustando las temáticas curriculares en base a las actualizaciones provenientes de los círculos de expertos.

Esa relación de envejecimiento y ajuste que plantea una dialéctica entre productores científicos y maestros enseñantes no tiene en cuenta, tal como plantea F. Terigi, el saber acerca del "cómo enseñar" que el docente produce en su misma práctica (2007, p. 100). No obstante, la presente contribución va más allá de esa sabiduría de la transmisión que la comunidad docente aporta como valor agregado al saber sabio. Hay una sabiduría que proviene de la traducción, tanto en la interculturalidad dentro de la propia lengua como en la interculturalidad que implica un esfuerzo ante la lengua extranjera. De este modo, la traducción da lugar a esa suerte de "traición virtuosa" del original que, alterando el saber experto de una cultura, propicia una novedosa ganancia epistémica.

La tesis expuesta a lo largo de este ensayo supone la comprensión de la traducción ya no a partir del esquema técnico del traductorado profesional o del mundo editorial. Se trata de entenderla como "metáfora" de una relación entre un yo y un otro en torno a un "casi lo mismo" cuya imposible mismidad da lugar a una ética de la co-participación en la producción de saber. De esta forma de entender la traducción dan cuenta, a su manera, pensadores como Benjamin, Ricoeur y Fornet-Betancourt. En el campo educativo, la dispersión y recreación de contenidos que nos ubica ante un "más allá de Babel” recoge los aportes de P. Freire, J. Larrosa o G. Steiner.

El planteo ya clásico de Chevallard, acerca del desgaste y la pérdida que se da en el proceso de trasposición resulta una obviedad, en cuanto a la relación entre productores científicos y docentes facilitadores. La capacitación y "puesta al día” del docente en ese 
terreno es un hecho que no se pone en duda. Lo que constituye un valor agregado en este caso es la ganancia epistémica que se genera en esas zonas de contacto donde la traducción -la no reducción de la cultura del otro- asiste a la producción de saberes contextuales e interculturales novedosos y de gran potencia ético-política.

\section{REFERENCIAS}

AGOGLIA, Rodolfo. La cultura como facticidad y reclamo. Cultura 5. Revista del Banco Central del Ecuador, Quito, 1982, p. 14-32.

BENJAMIN, Walter. La tarea del traductor. Angelus Novus. Barcelona: Edhasa, 1971.

BERISSO, Daniel.¿Qué clase de dar es el dar clase? Buenos Aires: Antropofagia, 2015.

BHABHA, Homi K. El lugar de la cultura. Buenos Aires: Manantial, 2002.

CASTRO GÓMEZ, Santiago. Ciencias sociales, violencia epistémica y el problema de la invención del otro. In: LANDER, E. (Org.) La colonialidad del saber eurocentrismo y ciencias sociales. Perspectivas latinoamericanas. Buenos Aires, CLACSO, 1993.

CASTRO-GÓMEZ, Santiago. Decolonizar la universidad. La hybris del punto cero. In.: CASTRO-GÓMEZ, Santigo; GROSFOGUEL, Ra mon (Org.) El giro decolonial: reflexiones para una diversidad epistémica más allá del capitalismo global. Bogotá: Siglo del Hombre Editores; Universidad Central, Instituto de Estudios Sociales Contemporáneos y Pontificia Universidad Javeriana, 2007, p. 79-93.

CHEVALLARD, Yves. La transposición didáctica, del saber sabio al saber enseñado. Buenos Aires: Aique, 1991.

DERRIDA, Jacques. El monolingüismo del otro Buenos Aires: Manantia, 1997.

ECO, Umberto. Decir casi lo mismo. Barcelona: Lumen, 2008.

FORNET-BETANCOURT, Raul. Interculturalidad y globalización. Ejercicios de crítica filosófica intercultural en el contexto de la globalización neoliberal. Costa Rica: Editorial DEI, 1997.

FORNET-BETANCOURT, Raul. Interculturalidad y filosofía en América Latina. Aachen: Wissenschaftsverlag Mainz, 2003.

FORNET-BETANCOURT, Raul. Tareas y propuestas de la Filosofía Intercultural. Aechen, Verlagsgruppe Mainz, 2009.

FREIRE, Paulo. Pedagogía de la Autonomía. México DF: Siglo XXI, 1997. (Trabajo original publicado en 1996). 
(1) URI|

FREIRE, Paulo. Pedagogía del oprimido. Madrid: Siglo XXI, 2010.

KUSCH Rodolfo. Esbozo de una antropología filosófica americana. Buenos Aires: Castaneda, 1987.

LARROSA, J Entre las lenguas. Lenguaje y educación después de Babel. Barcelona: Laertes, 2003.

MIGNOLO, Walter Capitalismo y geopolítica del conocimiento. Buenos Aires: Ediciones del signo, 2001.

MIGNOLO, Walter. Ciudadanía, conocimiento y los límites de la humanidade. In.:

KOZLAREK, Oliver; JÖRN, Rüsen. Humanismo en la era de la globalización. Desafíos y perspectivas. Buenos Aires: Biblos, 2009.

RICOEUR, Paul. Sí mismo como otro. México: Siglo XXI, 1996.

RICOEUR, Paul. Del texto a la acción. Buenos Aires: Fondo de Cultura Económica, 2000.

RICOEUR, Paul. Sobre la traducción. Buenos Aires: Paidós, 2005.

SALAS ASTRAIN, Ricardo. Ética Intercultural: ensayos de una ética discursiva para contextos conflictivos. Santiago de Chile: Editorial Universidad Católica Cardenal Raúl Silva Henríquez, 2003.

SANTOS, Jorge. Filosofía intercultural y pedagogía. Aportes de Paulo Freire. Tesis de Doctorado, Facultad de Filosofía y Letras Universidad de Buenos Aires. MIMEO, 2014.

SKLIAR, Carlos. ¿YY si el otro no estuviera ahí? Notas para una pedagogía (improbable) de la diferencia. Buenos Aires: Miño y Dávila, 2011.

STEINER, George. Después de Babel. México, Fondo de Cultura Económica, 2001.

TERIGI, Flávia. Exploración de una idea. En torno a los saberes sobre lo escolar. In.: BAQUERO, Ricardo; DIKER, Gabriela; Frigerio, Graciela (Orgs.) Las formas de lo escolar. Buenos Aires: Estante editorial, 2007, p. 99-115. 